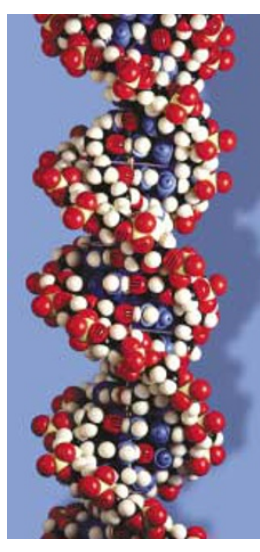

Learning how to manipulate DNA's double helix has fuelled job growth in biotechnology during the past 50 years, says Eugene Russo.

Stanley Cohen, one of the founders of modern-day biotechnology.

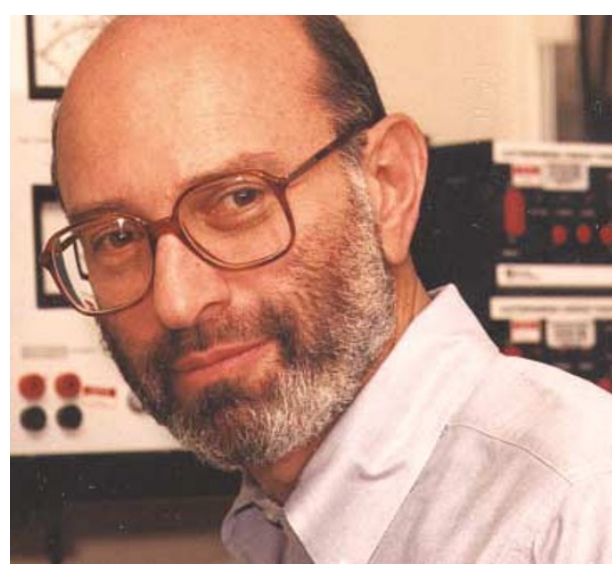

A ccording to one account, biotechnology was born during a meeting at a Hawaiian delicatessen in 1972. The shop has long since been torn down, and there is no plaque to mark biotech's inception - but its legacy lives on. And the two pioneers who met there blazed distinct career paths that have become well trodden.

Stanford medical professor Stanley Cohen and biochemist Herbert Boyer from the University of California, San Francisco, were in Honolulu to attend a meeting on plasmids, the ringlets of DNA contained in bacteria. Cohen reported on the ability to introduce plasmid DNA into Escherichia coli, which allowed researchers to propagate and clone the plasmids in the bacteria. Boyer told the meeting about his work with a revolutionary enzyme called EcoRI that could cleave the double-stranded DNA molecule to produce singlestranded ends with identical termini.

Both saw the potential for combining the two discoveries into what would become genetic engineering. First, use EcoRI to slice both plasmid DNA and the DNA of choice. Then, with the identical DNA termini exposed, attach the DNA fragment to the plasmid DNA, and clone the whole in E. coli.

The two men first discussed collaboration at a deli near Waikiki Beach. Their chat over a late-night snack led to a scientific achievement that later rocked the world of science. Within a year, they had cloned DNA molecules made by splicing together DNA fragments of two different plasmids, thus creating recombinant DNA. The foundations for biotechnology were established.

Boyer and Cohen chose different paths, both affected by concerns about the safety of recombinant DNA technology (which would lead in 1975 to the Asilomar conference, where scientists, ethicists and journalists pondered the implications of genetic engineering). While Cohen stayed in academia and defended recombinant DNA technology in US congressional hearings, Boyer saw the potential for profit. In South San Francisco in 1976 , Boyer and venture- capitalist Robert Swanson set up Genentech, the world's first biotechnology company.

Pioneers at Genentech and their collaborators at the California Institute of Technology were the first to synthesize DNA in the lab. But they wanted to use E. coli as a factory to synthesize mammalian proteins. Proof of principle had been demonstrated earlier by Cohen and his colleagues at Stanford, when they used the bacteria to produce a functioning mouse-cell protein. The Genentech scientists eventually succeeded, producing a human hormone called somatostatin in the bacteria - and so heralded the era of commercial biotechnology. The production of insulin and growth hormone followed soon after.

In the following years, a flood of biotech firms entered the scene. Harvard professor Walter Gilbert and Phillip Sharp at the Massachusetts Institute of Technology, now both Nobel laureates, set up Biogen in Geneva in 1978. Cetus, of Emeryville, California founded in 1971 as a 'bioengineering company' made the push towards biotechnology and, within ten years, developed the polymerase chain reaction, which amplifies DNA. Biotech firm Amgen of Thousand Oaks, California, started up in 1980 with less than 50 employees - it now has more than 10,000 worldwide.

\section{SCIENCE AND JUDGEMENT}

Gilbert, who is now a biotech start-up specialist, says that those who have survived in the industry made astute predictions. The industry began with a focus on human proteins made in bacteria and on antibodies, he says. It then moved on to immunological treatments for cancer, and small-molecule treatments for disease. In the 1990s came a wave of neurobiology companies, followed by a wave of genomics companies. "The people who made it are the ones who guessed right," he says.

"Partly it was really good biology, but partly it was really good judgment about doing problems that were going to work," says Leroy Hood, founder of the Institute for Systems Biology in Seattle, Washington.

New technologies have fuelled the biotechnology fire. Hood and Applied Biosystems, the company he founded in 1981 in Foster City, California, came up with the automated protein synthesizer, protein sequencer, DNA synthesizer and DNA sequencer. The first three Hood calls "sophisticated plumbing" problems, as they just involved engineering a series of 
valves to mix the correct quantities of reagents. The last was more sophisticated; it needed the integration of biology, chemistry, engineering and computer science.

Researchers also became more integrated. Many biologists joined the chemists working for big drug companies, and technological needs opened the field up to researchers with skills outside biology.

Such powerful technologies have changed the way biologists do science. 'Big science', once unique to chemistry and physics, has entered biology. Now, researchers no longer have to start their gene search with a hypothesis - with whole genomes at their disposal, they can find a gene by doing a quick database search, and then use those data in a hypothesis-driven manner for some further discovery.

\section{A CYCLICAL INDUSTRY}

Although the proliferation of big science and genomic data sparked a revolution, firms that depended too much on the human genome have faltered. Celera of Rockville, Maryland, which sequenced a draft of the human genome, has shed jobs in its effort to become a pharmaceutical company. And DoubleTwist of Oakland, California, which hoped to sell a 'superior' annotation of the human genome, went bankrupt last year.

According to Gilbert, stocks in the industry languished last year - but the industry itself did not. So small companies that are 3-5 years old are having trouble raising money at the exaggerated levels that they managed a few years ago. Gilbert says that promising new companies can still raise money just in smaller amounts.

As a result, Steve Burrill, chief executive of Burrill \& Company, a San Francisco-based biotech venturecapital firm, sees an industry with fewer jobs than in the past year, although some downsizing by older biotechs may have been offset by new start-ups. The demand for pharmacogenomics and bioinformatics expertise continues to grow, he says, along with the companies featuring them - much more than the rest of the industry. Burrill, who sees the industry as cyclical, expects both stock value and job opportunities to rebound within a year or two.

Richard Scheller, vice-president of research at Genentech, says that the company is not feeling much of a pinch, as it has a good number of products on the market. It recently hired ten new staff, and is building a new facility in South San Francisco. But even so, it is not hiring as many people as it did three years ago.

Burrill asserts that much of the restructuring in the drug industry has been good for biotech. Merging companies often shed staff, products and preclinical ideas that firms can pick up. And with pharmaceutical firms now bigger and more marketing-driven than ever, biotech companies remain important engines of innovation.

New technologies, meanwhile, continue to infuse the industry. Nanotechnology and pharmacogenomics, for example, are both areas of potential job growth. Gilbert sees 'lifestyle drugs' such as Viagra as the wave of the future - companies such as Memory Pharmaceuticals in Montvale, New Jersey, are trying to develop drugs that enhance memory and attention. Such prospects seem a far cry from the ideas raised at that Hawaiian deli more than a quarter of a century ago.

Eugene Russo is a freelance writer based in Takoma Park, Maryland.

\section{Birth of an industry}

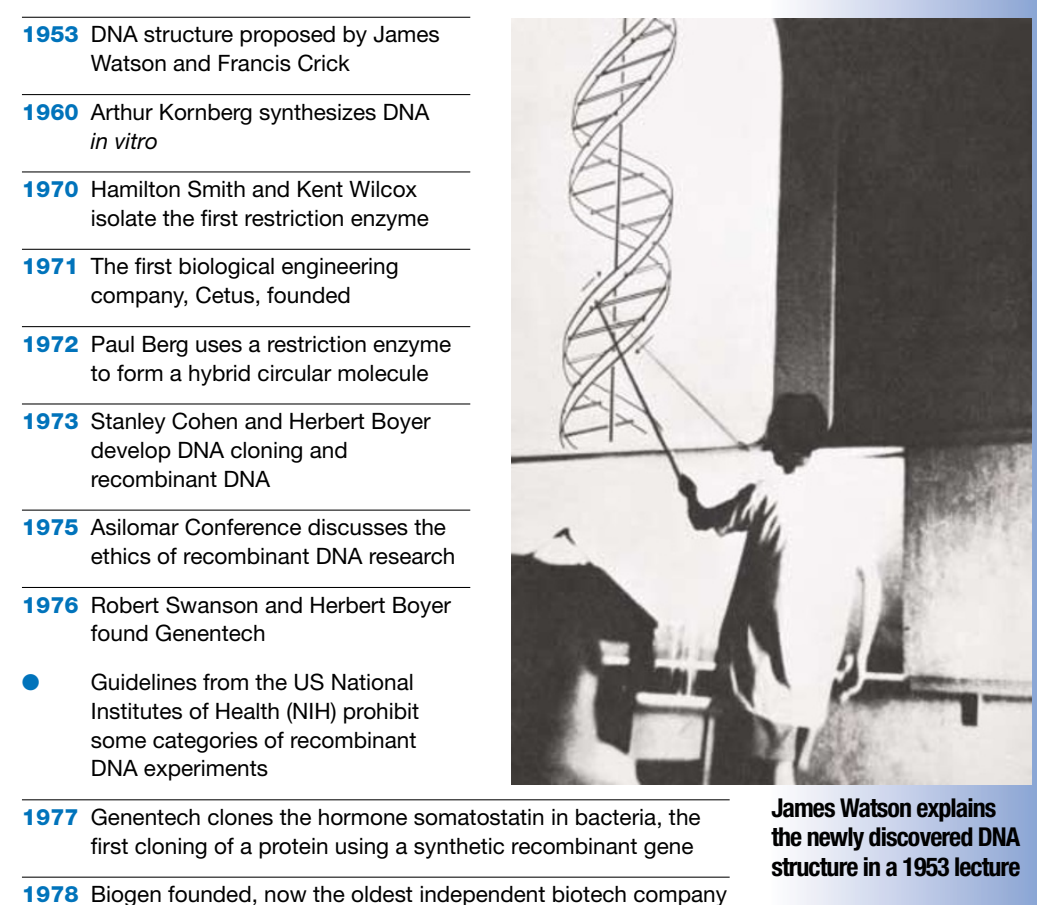

- Genentech and City of Hope National Medical Center announce the successful production of human insulin

$1979 \mathrm{NIH}$ recombinant DNA guidelines relaxed

- Genentech clones human growth hormone

1980 Amgen founded

- Leroy Hood and Mike Hunkapiller develop protein sequencer

- Fred Sanger and colleagues develop the shotgun method for sequencing genomes

- Bayh-Dole Act passes, encouraging technology transfer

- US Supreme Court decrees that life forms are patentable

1983 Kary Mullis invents the polymerase chain reaction

1986 US Environmental Protection Agency approves release of genetically altered tobacco, the first genetically engineered crop

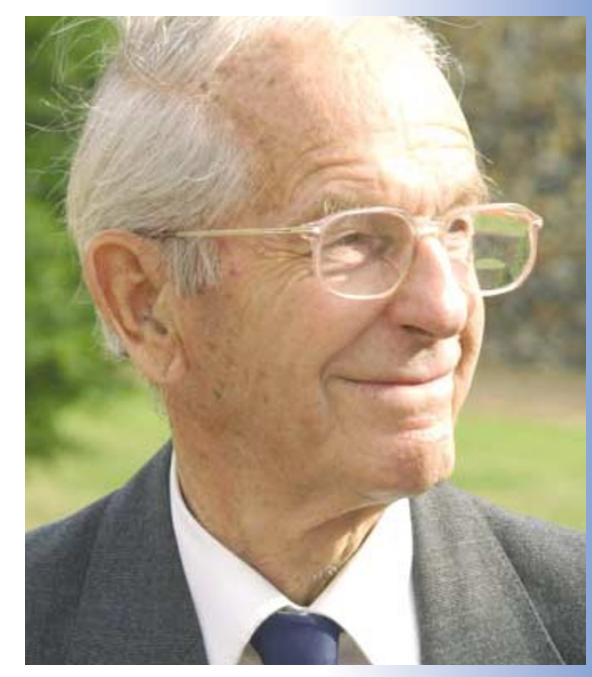

1987 Susan Horvath, Mike Hunkapiller and Leroy Hood develop DNA synthesizer

1988 Philip Leder and Timothy Stewart are awarded patent for mouse breast-cancer model, the first patent given for a genetically altered animal

1993 The Biotechnology Industry Organization (BIO) formed

1994 US Food and Drug Administration deems the Flavr Savr, a genetically modified tomato, safe, thus bringing to market the first transgenic food product

1997 Roslin Institute scientists clone Dolly the sheep, the first mammal to be cloned successfully from an adult cell

1998 Independent teams led by James Thomson and John Gearhart are the first to grow embryonic stem cells successfully

2001 Public and private teams publish draft versions of the human genome sequence

2002 Over 200,000 jobs exist across 4,000 biotech companies worldwide, according to analysts Ernst \& Young 